\title{
Development of Eco-adsorbent Based on Solid Waste of Paper Industry to Adsorb Cadmium Ion in Water
}

\author{
Eko Siswoyo and Shunitz Tanaka
}

\begin{abstract}
Eco-adsorbent prepared from paper sludge, a solid waste of paper industry, was studied to adsorb cadmium ion in water. Some parameters such as mass of the adsorbent, pH of solution, and shaking time were investigated in order to know the adsorption ability of the adsorbent. The presence of carboxyl and phenolic hydroxyl functional groups in this adsorbent were important in the process of adsorption. It was found that $\mathrm{pH} 6$ to 8 of solution and 60 minutes of shaking time was a suitable condition for this adsorbent in adsorbing cadmium ion. Langmuir isotherm adsorption model was fit for this adsorbent and the adsorption capacity for $\mathrm{Cd}(\mathrm{II})$ was 5.21 $\mathrm{mg} / \mathrm{g}$.
\end{abstract}

Index Terms-Cadmium, Eco-adsorbent, Langmuir, paper sludge carbon.

\section{INTRODUCTION}

The pollutions with heavy metal have become public concerns because of its potential damage to human health and environments. The high concentration of cadmium, one of most toxic metals, is very dangerous for human being and ecosystem. It can be released to the environment from many kinds of industrial activities such as ceramics, metal plating, textile, etc [1].

Itai-itai disease was one of the most severe environmental problems in Jinzu river area of Toyama prefecture, Japan. It is a disease caused by cadmium poisoning which brings softening of the bone and kidney failure. The rate of death among the patients was $72.6 \%$ and it was considered that itai-itai disease had a long-lasting negative effect on the patient's life span [2]. The concentration of cadmium in contaminated rice in the Jinzu area, one of most contaminated area in the past, was in the range between $0.02-1.06 \mathrm{ppm}$ [3]. In the Watarase river water near Ashio mine, the concentration of cadmium was 0.02-0.34 $\mu \mathrm{g} / 1$ [4]. Based on the standard of Japan minister of environment, the concentration of cadmium ion in water in public area should be less than $0.01 \mathrm{mg} / \mathrm{l}$. It is well known that heavy metals such as cadmium are accumulated in the livings and human body and its influence might be found out after several years. Therefore, even the low concentration of cadmium in water is still potential for kidney damage, bone damage, cancer, disturbing the respiratory and reproduction system due to the accumulation effect [5]. Generally, the concentration of

Manuscript received October 14, 2012; revised January 18, 2013.

Eko Siswoyo is with Graduate School of Environmental Science, Division of Environmental Science Development, Hokkaido University, Sapporo Kita-ku N10 W5, Hokkaido 060-0810, Japan. He is now also with Department of Environmental Engineering, Islamic University of Indonesia, Yogyakarta, Indonesia (e-mail: ekosiswoyo@ees.hokudai.ac.jp).

Shunitz Tanaka is with Graduate School of Environmental Science, Division of Environmental Science Development, Hokkaido University, Sapporo Kita-ku N10 W5, Hokkaido 060-0810, Japan. cadmium in aquatic environment of Japan is much lower in comparison with that of developing country such as Indonesia. The concentration of cadmium ion in the water area of Jakarta, the capital of Indonesia, was sometimes until $0.47 \mathrm{mg} / \mathrm{l}$, higher than the standard of Indonesian government (0.03 mg/l) [6].

Many technologies have been developed to solve the pollution problem of heavy metals, that is, membrane technology, ion exchange, phytoremediation, adsorption, etc. Activated carbon is a common adsorbent widely used in many countries. However, this material is expensive, therefore alternative materials are needed as a raw material of adsorbent for heavy metal ions.

Recently, around 5 million tons of paper sludge is discharged annually as solid waste from paper industry in Japan [7]. The disposal of paper sludge to the landfill or the treatment by incineration is high cost and may cause other environmental problem. Application of the paper sludge as a raw material of adsorbent has multi advantages, reducing amount of solid waste and cost for treatment and also providing a low cost adsorbent for removal of heavy metals. Paper sludge and other organic waste materials from paper industry could be considered as material of adsorbent due to their high carbon content and cellulose fibres proportion [8]. The adsorbent from paper sludge has the ability as an adsorbent for the removal of various kinds of heavy metal ions in water [9]. However, the application of paper sludge as adsorbent for adsorption of heavy metal ions is still limited.

The purpose of this study was to investigate the ability of paper sludge as raw material of adsorbent to adsorb cadmium ion in water.

\section{MATERIALS AND METHODS}

\section{A. Preparation of Adsorbent}

The Eco-adsorbent used in this study was prepared using paper sludge, a solid waste of a paper industry. The paper sludge carbon was provided from Doh-Ei Paper Mfg. Co., Ltd. in Sapporo city, Japan, where paper is produced from the used paper as main raw material. The paper sludge was produced during the paper production process. After dehydration and dryness of the paper sludge, it was treated at $950^{\circ} \mathrm{C}$ to form paper sludge carbon. The paper sludge carbon was washed with distilled water and dried at $100^{\circ} \mathrm{C}$ for 24 hours. After cooling it at room temperature, the paper sludge carbon were crushed into powder form and then sifted with a $1 \mathrm{~mm}$ sieve. The powdery paper sludge carbon is used as the adsorbent to adsorb cadmium ion from the water. The stock solution of cadmium ion $\left(\mathrm{Cd}^{2+}\right)$ was prepared with $\mathrm{Cd}\left(\mathrm{NO}_{3}\right)_{2} \cdot 4 \mathrm{H}_{2} \mathrm{O}$ of WAKO Pure Chemical Co (Osaka, Japan). 
Some physical and chemical characteristics such as surface area, pore size distribution, porosity, density, and main elements of the paper sludge carbon were determined using BELSORP-mini (BEL Japan INC, Osaka, Japan), FT/IR-4100 FT-IR Spectrometer (JASCO, Japan), and Element analyzer (MICRO CORDER JM10, Yanaco, Japan).

\section{B. Process of Adsorptions}

Adsorption process in this study was conducted by the batch system. Parameters such as mass of adsorbent, $\mathrm{pH}$ of the solution, shaking time and the concentration of cadmium ion in the solution were investigated to know the ability and the optimum condition for adsorption using this adsorbent. In order to estimate the effect of mass of the adsorbent, 0.1 to $2.0 \mathrm{~g}$ of adsorbent was added to $50 \mathrm{ml}$ of cadmium solution and agitated at $1000 \mathrm{rpm}$ for 24 hours using a shaker (EYELA CUTE MIXER CM-1000). The influence of $\mathrm{pH}$ on the adsorption of cadmium ion was investigated by using the solution of $\mathrm{pH} 2$ to 10 . Acetic acid, $\mathrm{HNO}_{3}$ and $\mathrm{NaOH}$ were utilized to adjust the desired pHs of solution. Various shaking time from 15 to 1440 minutes was applied to know the influence of shaking time on the adsorption of cadmium ion. After equilibrium, the solution was centrifuged at $4000 \mathrm{rpm}$ for 5 minutes using a centrifuge (IEC61010-2-020, KUBOTA, Japan) and then the concentration of cadmium ion in supernatant solution was determined using Flame Atomic Absorption Spectrophotometer (FAAS) (HITACHI A-2000, Japan).

The efficiency of adsorption is calculated by using the following equation:

$$
\text { Efficiency of adsoprtion }(\%)=\frac{C \text { intial }- \text { Cequilibrium }}{C \text { intial }} \times 100 \%
$$

\section{RESUlts AND Discussion}

\section{A. Characteristic of Adsorbent}

Based on the elemental analysis, the composition of main elements of paper sludge carbon were 19.4, 0.1, 16.3, 0.0, 0.0, and $64.2 \%$ for $\mathrm{C}, \mathrm{H}, \mathrm{O}, \mathrm{N}, \mathrm{S}$, and ash, respectively. The IR spectra of the paper sludge carbon suggested the presence of some functional groups such as carboxyl and phenolic hydroxyl group. These functional groups might participate in the adsorption of cadmium ion.

TABLE I: CHARACTERISTIC OF THE PAPER SLUDGE

\begin{tabular}{cc}
\hline Parameter & Value \\
\hline $\mathrm{pH}$ & 10 \\
Alkalinity & 0.17 \\
Surface area & $75.53 \mathrm{~m} 2 / \mathrm{g}$ \\
Porosity & 0.85 \\
Diameter & $3.8 \mathrm{~nm}$ \\
Pore capacity & $0.14 \mathrm{~cm} 3 / \mathrm{g}$ \\
Water adsorbed & $1.3 \mathrm{~g} / \mathrm{g}$ \\
Density & $400 \mathrm{~kg} / \mathrm{m} 3$ \\
\hline
\end{tabular}

Physicals and chemicals properties of the paper sludge carbon are shown in the Table I. According to the report from the paper company, silicate, calcium oxide and carbon were main elements of the paper sludge carbon and with 75.53 $\mathrm{m}^{2} / \mathrm{g}$ of surface area, this adsorbent may have a good performance in adsorbing cadmium ion in water. Fig. 1 shows the surface texture and porosity of this adsorbent captured using Analytical Scanning Electron Microscope (SEM) (JEOL JSM-6360 LA, Japan). These high porosity and large surface are essential for the high efficiency of adsorbent.

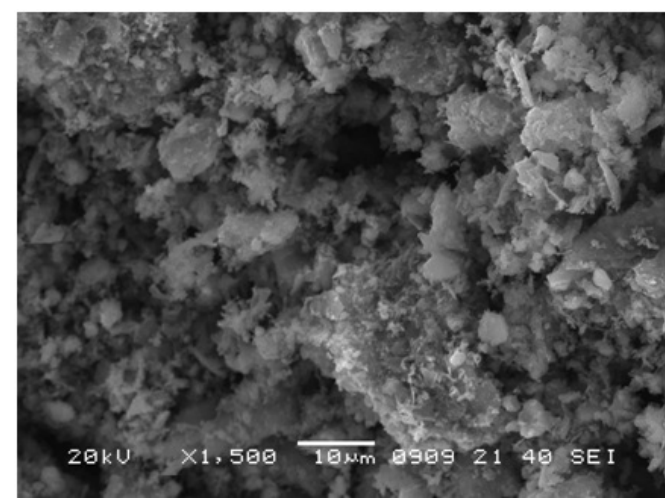

Fig. 1. SEM photograph of adsorbent

\section{B. Effect of Mass of Adsorbent}

Fig. 2 shows the removal efficiency of cadmium ion as a function of the mass of adsorbent. Increasing the mass of adsorbent led to the enhancement of the adsorption efficiency of cadmium ion in the water. The adsorption efficiency for cadmium ion increased increasing the mass of the adsorbent and became almost constant over $0.5 \mathrm{~g}$. For $50 \mathrm{ml}$ of cadmium solution, the favorable mass of adsorbent was $0.5 \mathrm{~g}$, where the adsorption efficiency was $95.35 \%$. The increase of the adsorption efficiency of cadmium ion is due to the greater availability of the binding sites or surface area [10].

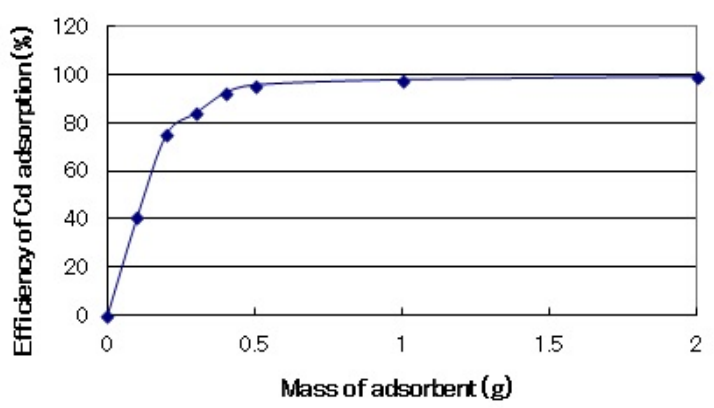

Fig. 2. Effect of mass of adsorbent on adsorption of cadmium ion (the $\mathrm{pH}$ of solution was 6.0 , shaking time 24 hours for $50 \mathrm{ml}$ of $10 \mathrm{mg} / \mathrm{l} \mathrm{Cd}(\mathrm{II}))$.

\section{Effect of pH of Solution}

The binding of $\mathrm{Cd}$ (II) with surface functional groups strongly depended on the $\mathrm{pH}$ of solution. The effect of $\mathrm{pH}$ on the adsorption of $10 \mathrm{mg} / \mathrm{l}$ cadmium ion is shown in the Fig.3. The percent removal of cadmium ion increased with $\mathrm{pH}$ of the solution because cadmium ion forms complex with some functional groups in the adsorbent. The removal of metal cation at any $\mathrm{pH}$ was much greater than that by hydroxide precipitation. Adsorption of metal cation on adsorbent depends upon the nature of adsorbent surface and the distribution of metal species which distribution also depends on the $\mathrm{pH}$ of the solution. The removal efficiency of cadmium decreased with the decrease of $\mathrm{pH}$, because protons compete with metal ion for the adsorption sites on the adsorbent surface as well as the ion existing decrease of negative charge by association of the functional group with proton. The increase in metal ion removal as $\mathrm{pH}$ increase can be 
explained on the basis of the decrease in $\mathrm{H}^{+}$on the surface, which results in less repulsion with adsorbing metal ions [11] and [12]. Rao M. M, (2006) reported that the point of zero charge of adsorbent was 5.7, where under 5.7 of $\mathrm{pH}$, the surface of adsorbent was positively charged and adsorption of metal ion was low due to the electrostatic repulsion. Another researcher mentioned that in the highly acidic medium, the dissolution of the adsorbent occurs to a consequent decrease in the active sites. In this condition, the adsorbent surface is highly protonated, which is not favorable for the uptake of cadmium ion because of the electrostatic repulsion [13] and [14].

The cadmium ion was precipitated when the $\mathrm{pH}$ of solution was 8.2 [15] and 9.0 [1] and [16]. In this study, it was confirmed that cadmium ions were precipitated at the higher $\mathrm{pH}$ than 8 . The ideal $\mathrm{pH}$ for adsorption of $10 \mathrm{mg} / \mathrm{l}$ of cadmium solution was within the range of 6 to 8 . The possible mechanisms of adsorption are shown as follows.

$$
\begin{gathered}
\mathrm{RO}^{-}+\mathrm{M}^{2+} \rightarrow \mathrm{ROM}^{+} \\
\mathrm{RO}^{-}+\mathrm{MOH}^{+} \rightarrow \mathrm{ROMOH} \\
\mathrm{ROH}+\mathrm{M}^{2+} \rightarrow \mathrm{ROM}^{+}+\mathrm{H}^{+} \\
\mathrm{ROH}+\mathrm{MOH}^{+} \rightarrow \mathrm{ROMOH}+\mathrm{H}^{+}
\end{gathered}
$$

where $\mathrm{RO}^{-}$denotes a negatively charged surface, $\mathrm{ROH}$ denotes a neutral surface and $\mathrm{M}$ denotes metal such as $\mathrm{Cd}$.

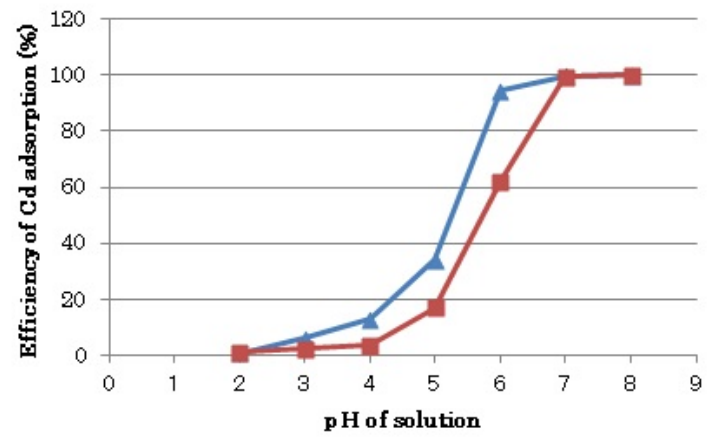

Fig. 3. Effect of $\mathrm{pH}$ of solution for $\mathrm{Cd}$ adsorption on the $0.01 \mathrm{M}$ ( $\square$ and $0.1 \mathrm{M}(\Delta)$ of buffer solution (adsorbent was $0.5 \mathrm{~g}$, shaking time 24 hours for $50 \mathrm{ml}$ of $10 \mathrm{mg} / \mathrm{l} \mathrm{Cd}(\mathrm{II}))$.

\section{Effect of Shaking Time}

The effect of shaking time on the adsorption of cadmium ion is shown in Fig. 4. The equilibrium adsorption for $10 \mathrm{mg} / \mathrm{l}$ of cadmium was achieved after around 30 minute with $85 \%$ adsorption capacity and then became $95 \%$ after 24 hours of shaking. This result is important because the equilibrium time is one of the considerations for the application of economical wastewater treatment plant [10].

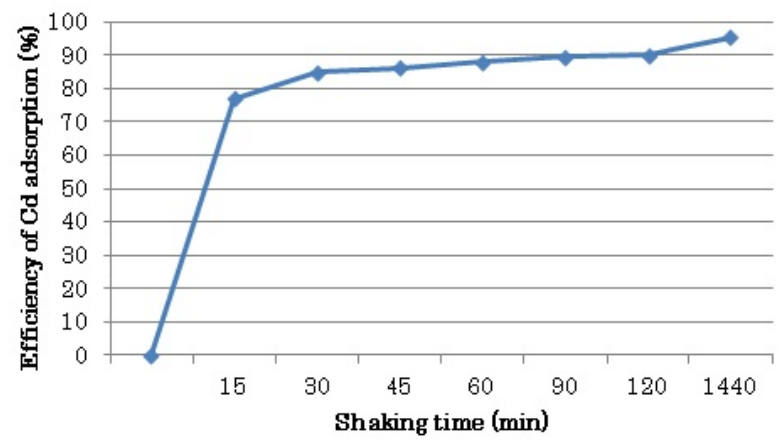

Fig. 4. Effect of shaking time on the adsorption of $\mathrm{Cd}(0.5 \mathrm{~g}$ adsorbent was used for $50 \mathrm{ml}$ of $10 \mathrm{mg} / \mathrm{l} \mathrm{Cd}(\mathrm{II})$ at $\mathrm{pH} 6.0$ )

\section{E. Isotherm of Adsorption}

The adsorption isotherm is shown in the Fig. 5. The Langmuir isotherm model was applied to the equilibrium constant of adsorption by the following equation:

$$
\frac{C_{e}}{q_{e}}=\frac{1}{q_{m}} C_{e}+\frac{1}{K_{L} q_{m}}
$$

where $\mathrm{C}_{\mathrm{e}}$ is the equilibrium concentration $(\mathrm{mg} / \mathrm{l}), \mathrm{q}_{\mathrm{e}}$ is the adsorbed amount of cadmium at equilibrium $(\mathrm{mg} / \mathrm{g}), \mathrm{qm}$ and $\mathrm{K}_{\mathrm{L}}$ are the constants of Langmuir related to the adsorption capacity and energy of adsorption, respectively. From the equation above, a plot of $\mathrm{C}_{\mathrm{e}} / \mathrm{q}_{\mathrm{e}}$ versus $\mathrm{C}_{\mathrm{e}}$ will be used to determine the values of $\mathrm{q}_{\mathrm{m}}$ and $\mathrm{K}_{\mathrm{L}}$ as the tangent and intercept of the curve. The value of $\mathrm{q}_{\mathrm{m}}, \mathrm{K}_{\mathrm{L}}$, and $\mathrm{R}^{2}$ determined from the above equation were $5.2 \mathrm{mg} / \mathrm{g}, 0.24$, and 0.9995, respectively.

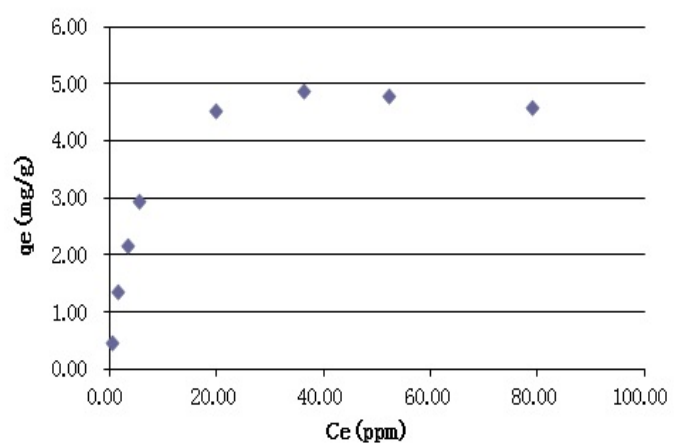

Fig. 5. Langmuir isotherm for adsorption of $\mathrm{Cd}$ (II) $(0.5 \mathrm{~g}$ adsorbent was used for $50 \mathrm{ml} \mathrm{Cd(II)} \mathrm{solution} \mathrm{of} \mathrm{pH}$ 6.0, and for 24 hours shaking time)

TABLE II: COMPARISON OF ADSORPTION CAPACITY WITH OTHERS

\begin{tabular}{lcc}
\multicolumn{1}{c}{ Adsorbent } & $\mathbf{q}_{\mathbf{m}}(\mathbf{m g} / \mathbf{g})$ & Reference \\
\hline Hematite & 0.244 & {$[13]$} \\
Fly ash pellets & 4.88 & {$[14]$} \\
Waste slurry & 15.73 & {$[15]$} \\
Perlite & 0.64 & {$[18]$} \\
Cushew nut shells & 14.29 & {$[19]$} \\
Olive stones & 0.83 & {$[20]$} \\
Dried activated sludge & 1.28 & {$[21]$} \\
Bagasse fly ash & 1.20 & {$[22]$} \\
Activated carbon from & 93.4 & {$[23]$} \\
coconut coirpith & 5.21 & This study \\
Paper sludge & &
\end{tabular}

The essential characteristics of the Langmuir isotherm can be expressed due to a dimensionless constant of the separation factor or equilibrium parameter, $\mathrm{R}_{\mathrm{L}}$, which is defined as:

$$
\mathrm{R}_{\mathrm{L}}=1 /\left(1+\mathrm{K}_{\mathrm{L}} \mathrm{C}_{0}\right)
$$

where $K_{L}$ is the Langmuir constant and $C_{0}$ is the initial concentration of cadmium ion in the solution. The $\mathrm{R}_{\mathrm{L}}$ value indicates the shape of the isotherm as follows:

$\begin{array}{ll}\mathrm{R}_{\mathrm{L}}>1 & \text { Unfavorable } \\ \mathrm{R}_{\mathrm{L}}=1 & \text { Linear } \\ 0<\mathrm{R}_{\mathrm{L}}<1 & \text { Favorable } \\ \mathrm{R}_{\mathrm{L}}=0 & \text { Irreversible }\end{array}$


The $R_{L}$ value between 0 and 1 is favorable adsorption [17]. The $R_{L}$ values for the concentrations of 10 and $150 \mathrm{mg} / \mathrm{l} \mathrm{Cd}^{2+}$ were 0.296 to 0.027 , respectively. It means that the adsorbent was favorable adsorption for cadmium ion. The comparison of this adsorbent with some materials can be seen in Table II. Compared to the other materials, this adsorbent is quite good and could be considered as a low cost adsorbent.

\section{CONCLUSION}

The ability of paper sludge carbon as a material of adsorbent for cadmium (II) is not so high, however, the application of this material will give some advantages such as reducing amount of solid waste in the landfill and decreasing cost for its treatment. Another benefit is that the paper sludge carbon has a magnetization property, therefore the development of a magnetic adsorbent based on the paper sludge for some heavy metal ions will give more advantages in the future.

\section{ACKNOWLEDGMENT}

The authors thank to GCOE program of Graduate School of Environmental Science, Hokkaido University, Instrumental Analysis Division, Equipment Management Center, Creative Research Institute, Hokkaido University and Doh-Ei Paper Mfg. Co., Ltd. Sapporo for financial support.

\section{REFERENCES}

[1] Y. Wang, X. Tang, Y. Chen, L. Zhan, Z. Li, and Q. Tang, “Adsorption behavior and mechanism of $\mathrm{Cd}(\mathrm{II})$ on loess soil from China," $J$. Hazardous Materials, vol. 172, pp. 30-37, 2009.

[2] S. Kawano, H. Nakagawa, Y. Okumura, and K. Tsujikawa, "A mortality study of patients with Itai-itai disease," Environmental Research, vol. 40, pp. 98-102, 1986.

[3] T. Ishihara, E. Kobayashi, Y. Okubo, Y. Suwazono, T. Kido, M. Nishijyo, H. Nakagawa, and K. Nogawa, "Association between cadmium concentration in rice and mortality in The Jinzu river basin, Japan," Toxicology, vol. 163, issue 1, pp. 23-28, 2001.

[4] K. Ohmichi, Y. Seno, A. Takahashi, K. Kojima, H. Miyamoto, M. Ohmichi, Y. Matsuki, and K. Machida, "Recent heavy metal concentrations in Watarase Basin around Ashio Mine," J. Health Science, vol. 52, no. 4, pp. 465-468, 2006

[5] J. Godt, F. Scheidig, C. Grosse-Siestrup, V. Esche, P. Brandenburg, A. Reich, and D. A. Groneberg, "The toxicity of cadmium and resulting hazards for human health," J. Occupational Medicine and Toxicology, vol. 1, pp. 22, 2006.

[6] E. Rochyatun and A. Rozak, "Observation on heavy metals in sediment of Jakarta bay water," Makara Sains, vol. 11 no. 1, pp. 28-36, April, 2007.

[7] J. Prasetyo, K. Naruse, T. Kato, C. Boonchird, S. Harashima and E. Y. Park, "Bioconversion of paper sludge to biofuel by simultaneous saccharification and fermentation using a cellulose of paper sludge origin and thermotolerant saccharomyces cerevisiae TJ14," Biotechnology for biofuels, vol. 4, pp. 35, 2011.

[8] Mendez, S. Barriga, J.M. Fidaldo and G. Gasco, "Adsorbent materials from paper industry waste materials and their use in $\mathrm{Cu}(\mathrm{II})$ removal from water," J. Hazardous Materials, vol. 165, pp. 736-743, 2009.
[9] Ochola and H. Moo-Young, "Evaluation of metal attenuation through paper clay utilized for containment of contaminated groundwater," $J$. Environmental Engineering, vol. 130, pp. 873-880, 2004.

[10] M. M. Rao, A. Ramesh, G. P. C. Rao, and K. Seshaiah, "Removal of copper and cadmium from the aqueous solutions by activated carbon derived from Ceiba petandra hulls," J. Hazardous Materials, B, vol. 129, pp. 123-129, 2006.

[11] Namasivayam and K. Ranganathan, 1995, "Removal of Cd(II) from wastewater by adsorption on waste $\mathrm{Fe}(\mathrm{III}) / \mathrm{Cr}$ (III) hydroxide," J. Water Resources, vol. 29, no. 7, pp. 1737-1744, 1995.

[12] R. Souag, D. Touaibia, B. Benayada, and A. Boucenna, "Adsorption of heavy metals $(\mathrm{Cd}, \mathrm{Zn}$ and $\mathrm{Pb})$ from water using keratin powder prepared from Algerien sheep hoofs," European Journal of Scientific Research, ISSN 1450-216X, vol. 35, no. 3, pp. 416-425, 2009.

[13] D. B. Sing, D. C. Rupainwar, G. Prasad, and K. C. Jayaprakash, "Studies on the Cd(II) removal from water by adsorption," J. Hazardous Materials, vol. 60, pp. 29-40, 1998.

[14] A. Papandreou, C. J. Stournaras and D. Panias, "Copper and cadmium adsorption on pellets made from fired coal fly ash," J. Hazardous Materials, vol. 148, pp. 538-547, 2007.

[15] S. M. Lee and A. P. Davis, "Removal of $\mathrm{Cu}(\mathrm{II})$ and $\mathrm{Cd}(\mathrm{II})$ from aqueous solution by seafood processing waste sludge," J. Water Research, vol. 35, issue 2, pp. 534-540, 2001.

[16] Siswoyo and S. Tanaka, "Removal of cadmium ion in water using sludge from drinking water treatment plant," Master thesis, Graduate School of Environmental Science, Hokkaido University, Japan, 2011.

[17] Mckay and H. S. Blair and J. R. Gardener, "Adsorption of dyes on chitin I. equilibrium studies," J. Appl. Polym. Sci. vol. 27, pp. 3043-3057, 1982.

[18] T. Mathialagan and T. Viraraghavan, "Adsorption of cadmium from aqueous solutions by perlite," J. Hazardous Materials, B94, pp. 291-303, 2002.

[19] S. Tangjuannk, N. Insuk, J. Tontrakoon, and V. Udeye, “Adsorption of Lead(II) and Cadmium(II) ions from aqueous solutions by adsorption on activated carbon prepared from cashew nut shells," Word Academy of Science, Engineering and Technology, vol. 28, pp. 110-116, 2009.

[20] Blazquez, F. Hernainz, M. Calero, and L. F. Ruiz-Nunez, "Removal of cadmium ions with olive stones: the effect of some parameters," Process Biochemistry, vol. 40, pp. 2649-2654, 2005.

[21] Khosravan and B. Laskari, "Adsorption of Cd(II) by dried activated sludge," Iranian Journal of Chemical Engineering, vol. 8, no. 2, pp. 41-56, 2011.

[22] V. K. Gupta, C. K. Jain, I. Ali, M. Sharma, and V. K. Saini, "Removal of cadmium and nickel from wastewater using bagasse fly ash-a sugar industry waste," Water Research, vol. 37, pp. 4038-4044, 2003.

[23] K. Kadirvelu and C. Namasivayam, "Activated carbon from coconut coirpith as metal adsorbent: adsorption of $\mathrm{Cd}(\mathrm{II})$ from aqueous solution," Advances in Environmental Research, vol. 7, pp. 471-478, 2003.

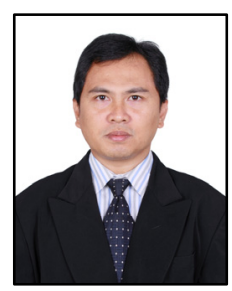

Eko Siswoyo was born at Lamongan, East Java, Indonesia on July 22, 1976. He received the Bachelor of Engineering - Department of Environmental Engineering, Institute Technology of Sepuluh November (ITS), Surabaya, Indonesia, 2001, the Master of Environmental Science (MSc.ES) Graduate School of Environmental Science, Hokkaido University, Japan, 2011 and the Master of Science (MSc.) - Graduate School of Environmental Science, Gadjah Mada University (UGM), Yogyakarta, Indonesia, 2012.

$\mathrm{He}$ is $\mathrm{PhD}$ student of Graduate School of Environmental Science, Hokkaido University, Japan. $\mathrm{He}$ is a lecturer at Department of Environmental Engineering, Faculty of Civil Engineering and Planning, Islamic University of Indonesia (UII), Yogyakarta, Indonesia from 2002 until now. Mr. Siswoyo is member of Japan Analytical Chemistry Society from July 2012. 